\title{
In Vitro Callus Induction from Adult Tissues of Japanese Flowering Cherry Trees and Two Cherry Rootstocks
}

\author{
Dragana M. SKOČAJIĆ ${ }^{1 *}$, Marija M. NEŠIĆ ${ }^{1}$, Marina Ž. NONIĆ ${ }^{1}$, \\ Milica M. FOTIRIĆ AKŠIĆ ${ }^{2}$, Mihailo N. GRBIĆ ${ }^{1}$, Matilda Š. ĐUKIĆ ${ }^{\text {, }}$ \\ Mirjana T. ŠIJAČIĆ-NIKOLIĆ ${ }^{1}$
}

\author{
${ }^{1}$ University of Belgrade, Faculty of Forestry, Department of Landscape Architecture, Kneza Višslava 1, 11030 Belgrade, Serbia; \\ dragana.skocajic@sfb.bg.ac.rs(*correspondingauthor); marija.nesic@sfb.bg.ac.rs; marina.nonic@sfb.bg.ac.rs; mihailo.grbic@sfb.bg.ac.rs; \\ matilda.djukic@sfb.bg.ac.rs; mirjana.sijacic-nikolic@sfb.bg.ac.rs \\ ${ }^{2}$ University of Belgrade, Faculty of Agriculture, Department Fruit Science and Viticulture Nemanjina 6, 11080 Belgrade, \\ Serbia;fotiric@agrif.bg.ac.rs
}

\begin{abstract}
Several in vitro biotechnological techniques have been developed, all of which require a reliable protocol to produce a responsive callus mass. One of these techniques is callus fusion in vitro, which is reliable for the early detection of (in)compatibility of scions and rootstocks. In this paper, the possibility to obtain friable callus tissues was explored by callus induction of adult tissues of Japanese flowering cherry trees from the group Sato zakura (Prunus serrulata 'Amanogawa', 'Kanzan' and 'Kiku-shidare-zakura') and two domestic cherry rootstocks - Prunus avium and Prunus 'Colt'. The explants used in the research were: leaf petiole, leaf base with a part of a petiole, part of lamina with a midvein and a stem with an axillary bud. Among three plant growth media (MS, SH and WP) that were used in this study, the MS proved to be the most favourable for the majority of taxa during the callus induction process. For the sweet cherry tree and the cultivars 'Kanzan' and 'Colt', the SH plant growth medium was also acceptable. The best results in callogenesis were obtained for the majority of taxons with auxin at the concentration $2 \mathrm{mgL}^{-1} \mathrm{NAA}$ and cytokinin BAP $0.5 \mathrm{mgL}^{-1}$. It is also possible to use 2.4-D at the same concentration as a substitute for the genotypes Prunus avium, Prunus 'Colt' and Prunus serrulata 'Kanzan', whereas IBA proved to be an inappropriate auxin for callus induction. The protocol described herein is proved to be efficient callus induction in a range of taxa of genus Prunus.
\end{abstract}

Keywords: callogenesis, explants, growth media, in vitro, Prunus serrulata, scion

Abbreviations: BAP-6-benzylaminopurine; 2.4-D-2.4-dichlorophenoxyacetic acid; DCC-degree of explant area covered by callus; IAA-indole-3-acetic-acid; IBA-indole-3-butyric-acid; MS-Murashige and Skoog medium; NAA- $\alpha$-naphtaleneaceticacid; PGRs-plant growth regulators; SH-Schenk and Hildebrandt medium; TDZ-1-Phenyl-3-(1,2,3-thiadiazol-5-yl)-urea (thidiazuron); WPM-Woody plant medium

\section{Introduction}

Flowering cherries (members of the Prunus subgenus Cerasus; Rosaceae) have been cultivated for more than 1000 years (Kato et al., 1999) and the economic and commercial importance is based on their attractive appearance, extensive vegetation, unpretentious growth conditions and high adaptation abilities (Kalinina and Brown, 2007). While research on the improvement of agronomic traits has been extensively conducted in the edible Prunus species (Caponeti et al., 1971; Jones and Hopgood, 1979; Garin et al., 1997; Miletić et al., 2008; Ružić et al., 2010; Mahdavian et al., 2011; Druart, 2013; Dorić et al., 2014) study of ornamental representatives of this genus is done on a much smaller scale, most probably due to fewer economic benefits. Published reports of tissue culture experiments of ornamental species have been limited for only a few of them: Prunus lannesiana Wils. (Matsuta et al., 1983), Prunus $\times$ yodensis Matsum. (Ishikura, 1994; Akita et al., 2006), eight ornamental cherries (Hokanson and Pooler, 2000), Prunus incisa 'February Pink' (Cheong and Pooler, 2004) and $P$. serrulata 'Kanzan' (Duta et al., 2007; Kalinina and Brown, 2007). 
For most purposes, in vitro callus establishment is important as an intermediate step in biotechnology and development of these biotechnological tools from mature tissues is important for the improvement of desirable commercial cultivars (Druart, 1980, 1999; Hammatt and Grant, 1998; Gentile et al., 2002; Bhagwat and Lane, 2004; Fajerska, 2006, Feeney et al., 2007). Callus is an amorphous and dedifferentiated, disorganized and non-homogeneous tissue produced by a plant as a response to insect or microorganism attack or stressful situations (George, 1993). Callus formation is triggered by the changes in the inner relation and transduction of endogenous hormones and environmental signals induce or maintain differentiation or dedifferentiation of callus cells (Mihaljević et al., 2002; Ikeuchi, 2013). Callus of Prunus sp. have been used for somatic organogenesis and embryogenesis, protoplast fusion, and hybridization (Druart, 1980, 1999; Jones et al., 1984; Garin et al., 1997; Tang et al., 2000). It has also been exploited in agricultural practices, horticulture, forestry and industry in order to achieve mass propagation of virus free plants (Neil and Neil, 2000; Akita et al., 2006; Feeney et al., 2007; Kalinina and Brown, 2007; Ružić et al., 2010). Many of these areas include working within the in vitro culture of the callus and one of the direction of the in vitro culture development are grafting compatibility of the rootstock and scion (Errea et al., 1994; 2001; Nito et al., 2005; Todić et al., 2005). A relatively reliable early detection of compatibilities/incompatibilities can be provided by an in vitro cultivation of fused callus tissues and monitoring the adhesion and the development of the cells at the point of union (Errea et al., 2001; Pina et al., 2009; Trinchera et al., 2013).

Ornamental Japanese flowering cherries from the Satozakura group, identified as the intraspecific taxa of the Prunus serrulata Lindl. have a special significance for landscape architecture and horticulture all over the world. Since the majority of them are grafted, the potential field of research is a callus induction of scions - commonly grown cultivars of ornamental cherries ( $P$. serrulata 'Amanogawa', 'Kanzan' and 'Kiku-shidare-zakura') and domestic cherry rootstocks (P. avium L. and Prunus 'Colt').

The aim of this study was to establish an efficient protocol for callus induction from adult tissue so that the results obtained can be further used for the compatibility testing by callus fusion. As in some cases adult tissue may be the only one that can be used to provide the tissue of a particular genotype (Druart, 1980; Declerck and Korban, 1996; Gentile et al., 2002; Pascual and Marin, 2005). Induction of calli from a petiole, leaf base, part of lamina and part of a stem with an axillary bud could indicate potentially the most suitable type of explant for callogenesis.

\section{Materials and Methods}

\section{Plantmaterial}

Plants tissues were collected from four year old nursery stock of the P. serrulata 'Amanogawa', 'Kanzan' and 'Kikushidare-zakura', and three year old rootstock $P$. avium and Prunus 'Colt' grown at the nursery open field. The young elongated branches, developed in the spring within the period of 4-5 weeks after the beginning of flowering were used as explant source for callus induction. The explants were surface sterilized in a solution of $2 \%(\mathrm{v} / \mathrm{v}) \mathrm{NaClO}$ containing $0.1 \%(\mathrm{v} / \mathrm{v})$ Tween 20 on a magnetic stirrer for 2h (Pérez-Jiménez et al., 2013) and rinsed three times in sterilized water for $10 \mathrm{~min}$.

\section{Culture conditions}

In sterile laminar air flow a scalpel was used to separate parts of the tissue used for callus induction: leaf petiole; leaf base with a part of the petiole; parts of a leaf lamina (blade) $0.5 \times 0.5 \mathrm{~cm}$ with a midvein; part of a young stem with an axillary bud (Fig. 1).

Explants were placed on agar-solidified culture mediums in the culture jars. The basal medium consisted of salts and vitamins of MS (Murashige and Skoog, 1962), WP (Woody Plant Medium; Lloyd and McCown, 1980) and SH (Schenk and Hildebrandt, 1972) medium and solidified with $0.65 \%(\mathrm{w} / \mathrm{v})$ agar. Explants of the three varieties of Sato-zakura cherries were grown on 9 , and 2 rootstocks $(P$. avium and Prunus 'Colt') on 6 different media. The total numbers of explants used in this study was between 240 and 360 per series ( 40 explants: leaf petiole + leaf base with a part of the petiole + leaf lamina + stem with an axillary bud per one treatment). The experiments were repeated 3 times for each treatment. The concentration $\left(\mathrm{mgL}^{-1}\right)$ and composition of plant growth regulators - PGRs -auxins 2.4-D (2.4-dichlorophenoxyacetic acid), NAA $(\alpha$ naphthylacetic acid), IBA (indole-3-butyric acid) and cytokinin BAP (6- benzylaminopurine) in different media are summarized in Table 1.

The basal medium was adjusted to $\mathrm{pH} 5.8$ and then sterilized by autoclaving at $121^{\circ} \mathrm{C}$ and 1.5 atm for $20 \mathrm{~min}$. In order to induce a white, fast growing friable callus tissue, all the explants were placed in glass jars (vessel) Ø $5.5 \times 5.5$ $\mathrm{cm}$ with $25 \mathrm{ml}$ of the medium and maintained at $23 \pm 2{ }^{\circ} \mathrm{C}$ under dark. In order to analyse the success of callus induction from different vegetative parts the following parameters were evaluated: percentage of callus induction, degree of explant area covered by callus (DCC) after a 30days expressed in percentages (Fig. 1) and the first day of callus induction. The friable callus tissues were cut into

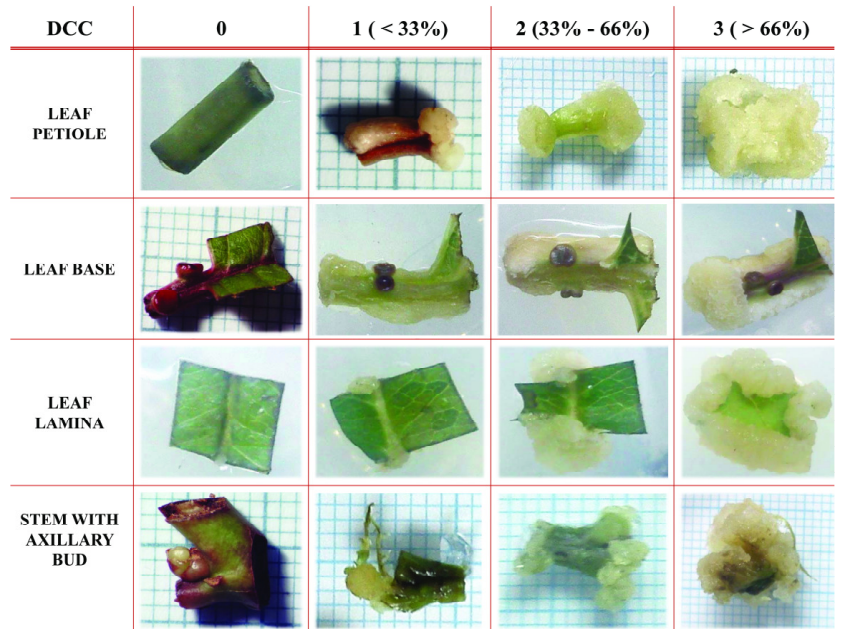

Fig. 1. Type of explants and degree of explant area covered by callus (DCC) 
394

Table 1. Composition of culture media and concentration of PGRs $\left(\mathrm{mgL}^{-1}\right)$ used for callus induction

\begin{tabular}{|c|c|c|c|c|c|c|c|c|c|c|c|c|c|c|c|}
\hline PGRs & & & & & & & Cult & e medi & i code & & & & & & \\
\hline $\mathrm{mgL}^{-1}$ & MS1 & MS2 & MS3 & MS4 & MS5 & WP1 & WP2 & WP3 & WP4 & $2.4 \mathrm{D}$ & 2 & & & & 2 \\
\hline BAP & 0.5 & 0.5 & 0.5 & 0.5 & 0.5 & 0.5 & 0.5 & 0.5 & 0.5 & 0.5 & 0.5 & 0.5 & 0.5 & 0.5 & 0.5 \\
\hline $2.4 \mathrm{D}$ & 2 & & & & 2 & 2 & & & & 2 & 2 & & & & 2 \\
\hline NAA & & 2 & & 2 & & & 2 & & 2 & & & 2 & & 2 & \\
\hline IBA & & & 2 & 0.5 & 0.5 & & & 2 & 0.5 & 0.5 & & & 2 & 0.5 & 0.5 \\
\hline
\end{tabular}

small pieces 4-5 mm wide and subcultures were maintained at the most appropriate medium of regular time period (30 days) under the same condition of light (dark) and temperature $\left(23 \pm 2^{\circ} \mathrm{C}\right)$.

\section{Statistical analysis}

Data were analysed by analysis of variance (ANOVA). The mean values were compared using post-hoc LSD Multiple Range test. Before the analysis, data presented in the form of percentage were subjected to arcsine transformation. The differences between treatments were considered significant at $\mathrm{p} \leq 0.05$ and designated by different letters. All statistical analyses were done with software StatgraphicsPlus Centurion XVI.

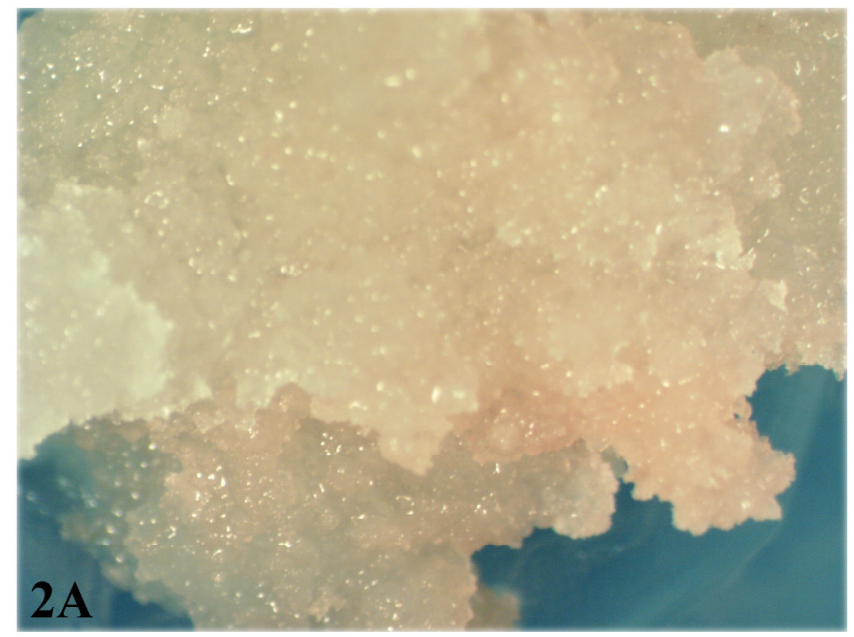

\section{Results}

The results indicated that it is possible to use the adult tissue of the vegetative parts of spring (young) shoots of the $P$. serrulata 'Amanogawa', 'Kanzan', 'Kiku-shidare-zakura', P. avium and Prunus 'Colt' as the source of explants for callus induction. During of induction of callus friable and nodular callus were obtained (Fig. 2). Samples with globular callus were discarded since they were not in line with the aim of this research.

All four types of $P$. serrulata 'Amanogawa' explants induced a callus on the MS media in a very high percentage (83.3\% to $100 \%)$. The selection of any of the auxins: $2.4-\mathrm{D}$, NAA or IBA supplemented with $0.5 \mathrm{mgL}^{-1} \mathrm{BAP}$ on the MS medium did not have an important role in increasing or reducing callus formation (Fig. 3A).

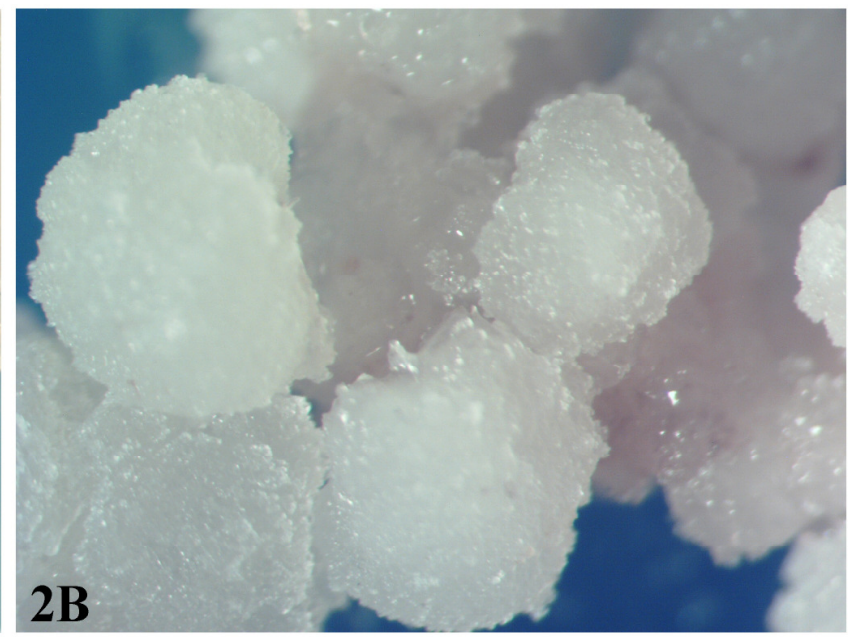

Fig. 2. Different types of callus A) friable callus; B) compact nodular callus
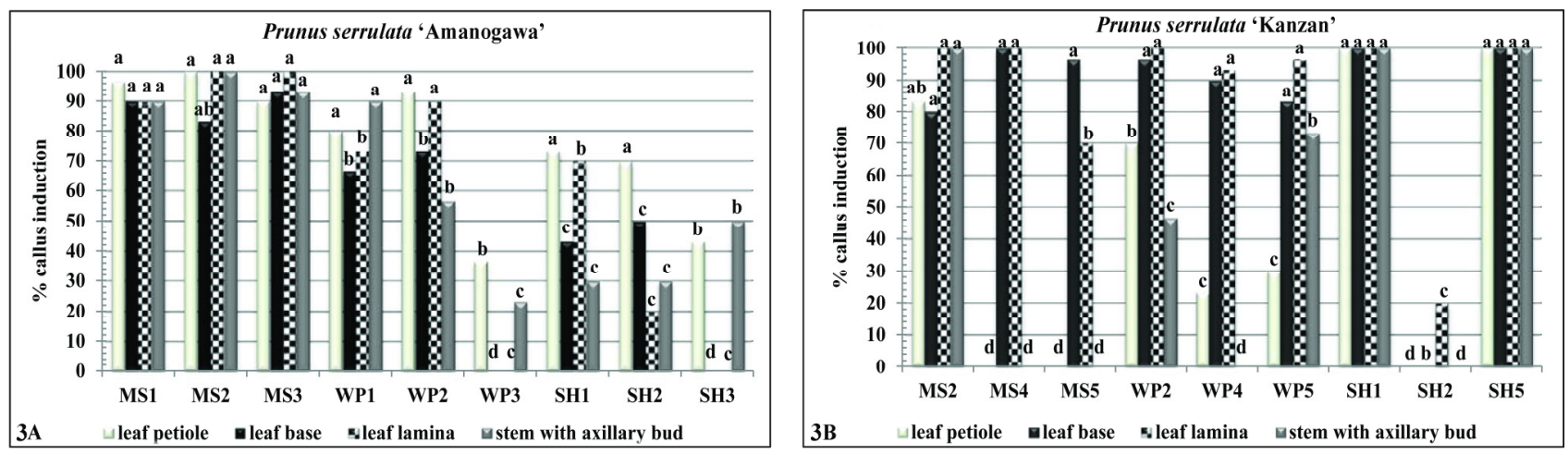

Fig. 3. Percentage of callus induction of $P$. serrulata 'Amanogawa' and 'Kanzan' explants on different culture medium. Each bar represents the mean of three replicates. Different letters at the vertical bars denote a significant difference at $p<0.05$ 
When WP nutrient medium was used with 2.4-D and NAA for petiole explants, leaf lamina and a part of a stem with an axillary bud significantly higher percentage of callus induction was recorded (Fig. 3A). On the media with IBA, callus induction was not recorded on the leaf base and the leaf lamina. However, induction was $23.3 \%$ on the petiole and $36.7 \%$ on the stem with an axillary bud. On the SH1 and $\mathrm{SH} 2$ media with 2.4-D and NAA, the callus was induced on about $70 \%$ of the petiole. In addition, when the leaf lamina was used on the SH1 medium the similar results were obtained (Fig. 3A). Other types of explants on the $\mathrm{SH}$ medium induce the callus in percentages lower than $50 \%$. Explants from the leaf base and leaf lamina did not show a positive reaction to IBA on the $\mathrm{SH}$ medium (the value of the induction on $\mathrm{SH} 3$ is $0 \%$ - Fig. 3A). The first appearance of callus formation on the explants of the stem with an axillary bud was observed very early, on the third day and on the leaf lamina on seventh day. The appearance of callus formation on parts of the shoot and the leaf petiole was completed by day 20 on all explants. In addition, for these two types of explants growth dynamics was the most intense (Table 2).

As shown in Fig 3B, the highest percentage of callus induction of all types of $P$. serrulata 'Kanzan' explants on $\mathrm{SH} 1$ and $\mathrm{SH} 5$ was in treatment with auxin 2.4-D at the concentration $2 \mathrm{mgL}^{-1}$, with or without $0.5 \mathrm{mgL}^{-1} \mathrm{IBA}$ and $0.5 \mathrm{mgL}^{-1}$ BAP. However, results showed that NAA in the $\mathrm{SH}$ medium leads to a drastic decreasing of the induction, which was below $20 \%$ for all types of explants. When the above mentioned ratio of all three PGRs was applied in the MS5 medium, 96.6\% of the explants from the leaf base induced the callus, as well as on WP5 with the percentage of 83.3 and 96.7 on the leaf base and the leaf lamina, respectively (Fig. 3B).

In contrast, the MS5 medium does not initiate callus on the part of the stem with an axillary bud and on a petiole. On MS2 for all the explants the induction was over $80 \%$ and on MS4, WP2 and WP4 it was over 95\% for the leaf base and the leaf lamina. From the Fig. 3B, it can be seen that both types of explants, which contained a part of the leaf lamina (the leaf base or the leaf blade itself) yielded a high percentage of induction for almost all the media. Similarly, results showed that when the mean value of the days of the induction and the first day when the callus appeared are considered, the leaf lamina and the leaf base explants are the most suitable ones (Table 2).

The poorest results for the callus induction from the vegetative parts of the shoot were obtained for the cultivar $P$. serrulata 'Kiku-shidare-zakura'. The induction reached about $70 \%$ only on three media (MS2, WP1 and WP5) and two types of explants (leaf petiole and part of a stem with an axillary bud - Fig. 4).
This is the only cultivar in which $2 \mathrm{mgL}^{-1} \mathrm{IBA}$ proved to be favourable for callus induction (the MS3 medium). The same was observed on WP1 but with the addition of 0.5 $\mathrm{mgL}^{-1}$ IBA supplemented with $2 \mathrm{mgL}^{-1} 2.4-\mathrm{D}$ (the WP5 nutrient medium) the callus was induced on about $50 \%$ of the explants of this type (Fig. 4). The induction in this cultivar also began very early (from 5th to 7th day). In case of all explants the induction process was completed on day 12 , except for the leaf lamina. No significant differences were found between the mean day of the first observation of callus formation on the explants of the leaf petiole, the leaf base and the shoot (Table 2). The results showed that the leaf lamina is the least favourable type of explant based on the speed and intensity of callus formation.

All six selected culture media proved to be suitable for callus induction from the vegetative parts of a sweet cherry shoot $(P$. avium $)$. The mean value of the induction for all types of media and explants exceeded $75 \%$ and a statistically significant difference was present only on the MS4 medium for the part of a stem with an axillary bud. Presence of only one auxin at the concentration of $2 \mathrm{mg}^{-1}$ (NAA on all three media, or 2.4-D on WP) was sufficient for callus induction (Fig. 5A).

It should be noted that for this type of explant (part of a stem with an axillary bud), the process of callus proliferation in in vitro culture of the callus can be classified as a very fast and intense process since the beginning of this process was on 9th day (Table 2).

Unlike the sweet cherry, the callus of the cultivar 'Colt' did not induce intensively on all the selected media. The induction of about $70 \%$ of the explants only occurred on the MS2 medium, while it was partially successful only for a certain type of explants, on SH2 and WP2 (Fig. 5B). Auxin

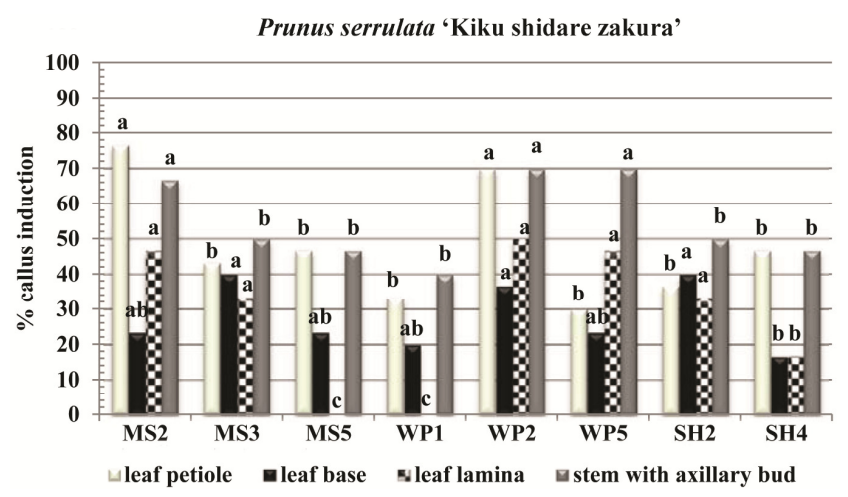

Fig. 4. Percentage of callus induction and DCC of P. serrulata 'Kiku shidare zakura' explants on different culture medium. Each bar represents the mean of three replicates. Different letters at the vertical bars (series) denote a significant difference at $\mathrm{p}<0.05$

Table 2. Callus induction responses and days of culture required for callus initiation for five genotypes of cherries

\begin{tabular}{ccccc}
\hline Cultivars & \multicolumn{2}{c}{ Mean day of callus induction ${ }^{\mathrm{a}}$} \\
\cline { 2 - 5 } & Leaf petiole & Leaf base & Leaf lamina & Stem with axillary bud \\
\hline P. serrulata 'Amanogawa' & $7^{\mathrm{b}}$ & $11.9^{\mathrm{a}}$ & $13.7^{\mathrm{a}}$ & $6.4^{\mathrm{b}}$ \\
P. serrulata 'Kanzan' & $15.22^{\mathrm{a}}$ & $9.12^{\mathrm{ab}}$ & $9^{\mathrm{b}}$ & $17.2^{\mathrm{a}}$ \\
P. serrulata - 'Kiku shidare zakura' & $8.9^{\mathrm{b}}$ & $8.12^{\mathrm{b}}$ & $13.67^{\mathrm{a}}$ & $7.68^{\mathrm{b}}$ \\
P. avium & $6^{\mathrm{b}}$ & $6.3^{\mathrm{b}}$ & $10.5^{\mathrm{a}}$ & $6.16^{\mathrm{b}}$ \\
P. 'Colt' & $10.83^{\mathrm{a}}$ & $9.5^{\mathrm{a}}$ & $10.5^{\mathrm{a}}$ & $14.6^{\mathrm{a}}$ \\
\hline${ }^{\mathrm{a}}$ Different letrers in the same column denote a significant difference, $\mathrm{p}<0.05$ & & &
\end{tabular}

${ }^{2}$ Different letters in the same column denote a significant difference, $\mathrm{p}<0.05$ 
396

2.4-D in the media did not have a great effect on the induction of $40 \%$ (MS1, WP1 and SH1). According to the explant type, the leaf petiole showed a statistically significant value of the induction on the MS2 and WP2 media in relation to the other ones (Fig. 5B). However, the degree of callus coverage on WP2 was about 33.3\%, which favoured the MS2 medium where coverage was $73 \%$. The MS2 medium proved to be the most suitable for other types of explants as well (Fig 5B). The appearance of the first signs of callus on the explants was observed very early (between days 6 and 9). There were no significant differences between the mean values of the day when the callus induction was observed on all types of explants (Table 2).

In regards to the results of the percentage of callus induction and DCC the suitability of a particular type of explants were analysed. The results are shown in the Table 3.

The results showed that the petiole is a very suitable type of explant for $P$. avium and $P$. serrulata 'Amanogawa' (95.55\% and $75.92 \%$ of the induction, respectively; $85 \%$ and $63 \%$ of the callus coverage, respectively). The values obtained for $P$. avium were significantly higher compared to values for other species. For other cultivars, the percentage reached about $50 \%$ of the induced explants and the coverage was between $32.72 \%$ and $53.41 \%$ with no significant difference between the values of both parameters (Table 3 ). More than $80 \%$ of the surface of over $80 \%$ of the leaf base and lamina explants from $P$. avium and $P$. serrulata 'Kanzan' was covered with the callus. In the cultivars $P$. serrulata 'Amanogawa' and Prunus 'Colt', this percentage significantly dropped to about $50 \%$ of the induced explants with the callus coverage of $55.04 \%$ and $38.16 \%$. Results showed that $30 \%$ of samples of the leaf base of $P$. serrulata 'Kiku-shidare-zakura', formed the callus with coverage of $45.87 \%$. The part of a stem with an axillary bud, as a type of explant of the sweet cherry, induces the callus in the percentage of $90.53 \%$, and this value is significantly higher in relation to all the others except for the value of $62.57 \%$ which was observed for the cultivar $P$. serrulata 'Amanogawa'. The value of this parameter was about 50\% for $P$. serrulata 'Kanzan' and 'Kiku-shidare-zakura' and $33.3 \%$ for 'Colt' (Table 3).

\section{Discussion}

The results obtained in this paper with ornamental cherries from the group Sato-zakura offer evidence of ability of adult tissue to be successfully used in callogenesis. Young grafted seedlings (as is the tissue of the Japanese cherries) are particularly suitable for donor plants for the in vitro culture. Namely, in the process of grafting, when in the majority of cases adult tissue (scion) is grafted onto a juvenile one (rootstock), the re-juvenility of the scion tissue is confirmed (Grbić, 2004). Favourable properties of physiological rejuvenility of the tissue has been confirmed with experiments on the peach (Pérez-Jiménez et al., 2013) or the bird cherry (Caponetti et al., 1971) where the effect of intensive callogenesis was achieved in the juvenile and re-juvenile tissue compared to the adult one. The problem of physiological age of the tissue which is introduced into the culture was dealt by Pascual and Marin (2005). The authors worked with 4 types of grafting rootstock of the genus Prunus revealing a process in which older leaves can be efficiently used in organogenesis. Also, they conducted a pretreatment in liquid phase with the addition of $2.4-\mathrm{D}$ increased the stimulation of callus formation in older tissue clearly demonstrated the role of growth regulators on the process of induction, proliferation and organogenesis of the callus.

Table 3. Analysis of variance for the mean values expressed in percentages referring to callus induction and degree of callus coverage $-\mathrm{DCC} \pm(\mathrm{SE})^{\mathrm{a}}$ (ANOVA, $\mathrm{p}<0.05)$

\begin{tabular}{|c|c|c|c|c|c|c|c|c|}
\hline Type of explant & \multicolumn{2}{|c|}{ Leaf petiole } & \multicolumn{2}{|c|}{ Leaf base } & \multicolumn{2}{|c|}{ Leaf lamina } & \multicolumn{2}{|c|}{ Stem with axillary bud } \\
\hline Cultivars & $\%$ callus induction & DCC (\%) & \% callus induction & $\overline{\mathrm{DCC}}(\%)$ & $\%$ callus induction & $\operatorname{DCC}(\%)$ & $\%$ callus induction & $\operatorname{DCC}(\%)$ \\
\hline P. serrulata 'Amanogawa' & $75.92 \pm 7.61^{\mathrm{ab}}$ & $63 \pm 8.84^{\mathrm{ab}}$ & $55.54 \pm 11.88^{\mathrm{b}}$ & $55.04 \pm 13.39^{\mathrm{ab}}$ & $60.37 \pm 13.982^{b}$ & $54.77 \pm 12.52^{\mathrm{ab}}$ & $62.57 \pm 10.34^{\mathrm{ab}}$ & $53.51 \pm 10.18^{\mathrm{ab}}$ \\
\hline P. serrulata 'Kanzan' & $45.17 \pm 14.39^{c}$ & $36.29 \pm 12.46^{c}$ & $82.94 \pm 10.66^{a}$ & $80.96 \pm 10.4^{a}$ & $86.65 \pm 8.94^{a}$ & $73.81 \pm 8.47^{a}$ & $46.66 \pm 15.79^{b}$ & $49.77 \pm 15.91^{\mathrm{ab}}$ \\
\hline P. serrulata 'Kiku shid zak' & $47.91 \pm 5.96^{c}$ & $52.41 \pm 6.88^{\mathrm{bc}}$ & $27.91 \pm 3.33^{c}$ & $45.87 \pm 8.32^{\mathrm{b}}$ & $28.34 \pm 7.23^{c}$ & $34.38 \pm 9.27^{\mathrm{b}}$ & $55.01 \pm 4.22^{\mathrm{b}}$ & $59.45 \pm 3.43^{\mathrm{ab}}$ \\
\hline Prunus avium & $95.55 \pm 3.29^{\mathrm{a}}$ & $85.61 \pm 9.70^{\mathrm{a}}$ & $97.21 \pm 1.18^{\mathrm{a}}$ & $84.05 \pm 7.79^{a}$ & $94.98 \pm 1.84^{a}$ & $32.72 \pm 4.17^{b}$ & $90.53 \pm 4.34^{a}$ & $82.61 \pm 11.5^{\mathrm{a}}$ \\
\hline Prunus 'Colt' & $50.55 \pm 8.31^{\mathrm{bc}}$ & $32.72 \pm 10.15^{c}$ & $46.66 \pm 9.27^{\mathrm{bc}}$ & $38.16 \pm 5.31^{\mathrm{b}}$ & $42.76 \pm 9.27^{\mathrm{bc}}$ & $36.89 \pm 5.31^{\mathrm{b}}$ & $33.33 \pm 12.17^{b}$ & $27.05 \pm 10.9^{b}$ \\
\hline
\end{tabular}
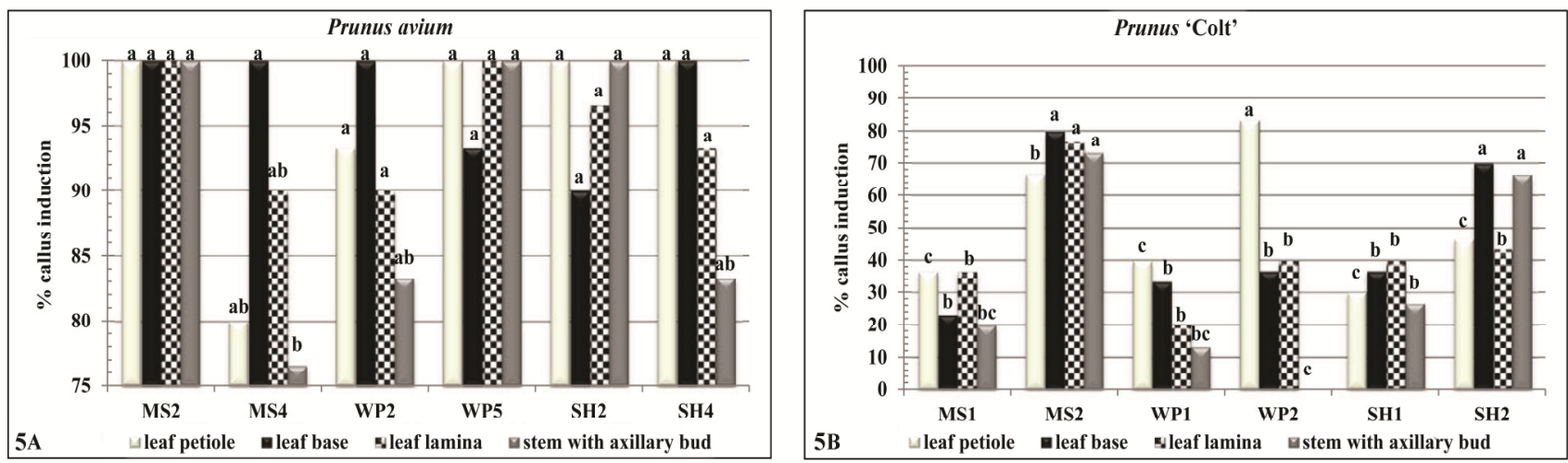

Fig. 5. Percentage of callus induction and DCC of P. avium and Prunus 'Colt' explants on different culture medium. Each bar represents the mean of three replicates. Different letters at the vertical bars denote a significant difference at $\mathrm{p}<0.05$ 
During the callus induction, plants produced different types of callus, which can be divided into subgroups based on their macroscopic characteristics (Ikeuchi et al., 2013). According to those authors callus without organ regeneration are frequently characterized as friable or compact callus. In order to investigate grafting compatibility by callus fusion, plant regeneration from callus (embryogenesis or organogenesis) was is not desirable and only the friable type of callus was is used (Errea et al., 1994, 2001; Mng'omba et al., 2008). According to Pina et al. (2009) callus does not have predictable organization pattern, it is composed of mass of loosely arranged and thin walled parenchyma cells. The undifferentiated cells, cells in the meristem and the elongation zone are symplasmically well connected, but gradually become isolated as they differentiate (Duckett et al., 1994). It is likely that also newly formed callus tissues are divided into symplasmic domains (Pina et al., 2009). For our further research of compatibility of flowering cherries and two cherry rootstocks, it was important to maintain callus as undifferentiated, friable, semi translucent, watery and crumbling.

Through the induction of the callus from the vegetative parts, the obtained results indicate that in the majority of genotypes the impact on the induction depended on the type of explant, combinations of PGRs, selection of the nutrient medium, as well as the genotype itself. Only in the case of the sweet cherry all nutrient media were suitable for callus induction. The noticed differences were dependable for PGRs concentration. Similar results, in which variations in the formation of the callus were depended on the type of explant, were obtained in many woody plants (Pierik, 1987; Gaspar et al., 1996; Siwach et al., 2011). As for P. avium and $P$. serrulata 'Amanogawa', the results showed that the leaf petiole is very suitable as a type of the explant for the callus induction. The leaf lamina had a similar distribution of values for both measured parameters as well as the leaf base, except that the degree of the callus coverage is lower in all the species and cultivars. The stem with an axillary bud, as a type of explant, induced the callus in the high percentage only in the sweet cherry. Confirmation of overconsumption callus induction was obtained in many works in Prunus species: explants the leaves and leaf petiole on apple (Yao et al., 1995); with cultivars of sour and sweet cherries (Tang $e t$ al., 2000; Matt and Jehle, 2005), on the explants of almond (Ainsley et al., 2000) and petiole of peach (Zhou et al., 2010).

The selected auxins and cytokinin were exogenously added to the nutrient medium in a ratio which was not less than 4:1 (auxin : cytokinin). The reason why the ratio of auxins was at a higher level in relation to the level of cytokinin was the reaction of dedifferentiated cells during the induction to exogenous PGRs. In the process of indirect organogenesis, dedifferentiated cells first start to actively divide and form the callus, after which (depending on the hormonal stimulus) localized meristematic centers continue to form the callus, or become differentiated into buds or roots. According to Nešković et al. (2010) the composition of the medium becomes inductive so calli need to remain on the medium for 10 to 14 days in order to become determined for a specific morphogenetic pathway. Considering the fact that after the induction period, the type of regeneration cannot be changed, the selection of the ratio of auxin and cytokinin in the process of work, as was already mentioned, was affected by the fact that only a relatively high ratio of auxin and a low ratio of cytokinin enables the callus tissue to continue to grow, which was the main goal of this paper. In addition, a permanent callus growth is attained only with both hormones (Mihaljević $e t$ al., 2002; Jayaraman et al., 2014). According to Fajerska (2006) the leaf lamina gives a very poor induction when only auxin is used in the medium. In the research of Vujović et al. (2010), the callus induction for the blackberry cultivar 'Čačanska Bestrna' was observed on all the combinations of different concentrations of auxin and cytokinin in the MS culture medium in a high percentage. While working with different vegetative parts of peach shoots, Pérez-Jiménez et al. (2013) also achieved a very high percentage of callus induction in the use of different concentrations of auxin (2.4-D) and cytokinin (kinetin and TDZ). In our investigation the selection of auxins, NAA proved to be the most efficient in callus induction for the majority of the tested genotype. In the induction process, satisfactory results were obtained by using 2.4-D, while IBA did not prove to be appropriate auxin for the induction. This result is in agreement with the results obtained for various rootstocks of the genus Prunus (Pascual and Marin, 2005), as well as with the results obtained with the almond (Işikalan et al., 2010) and Japanese ornamental plum (Ning et al., 2007). As the objective of this paper is the induction of callus without organogenesis, the selection of BAP was absolutely suitable as well as the ratio in which the amount of cytokinin was four times lower than the concentration of auxin.

Another important factor that undoubtedly had an impact on the induction of callus in the tested genotypes was the selection of a nutrient medium. It can be said that the MS medium proved to be the most suitable but different results were observed in callus induction on the other two media. The callus of $P$. serrulata 'Amanogawa' was induced on the MS media in a very high percentage regardless of the choice of auxins. In the case of the cultivar 'Kanzan', the SH medium with auxin 2.4-D were used and the induction was $100 \%$ on all types of explants. In research studies of Prunus mume Sieb. et Zucc (Ning et al., 2007) the callus induction was not established on hormone free nutrient medium, but on the $1 / 2 \mathrm{MS}$ medium with the ratio of 4:1 - auxin NAA or 2.4-D:cytokinin BAP, the callus induction ranged from $81.6 \%$ to $97 \%$. The results obtained by the induction of different types of explants from $P$. avium (Neil and Neil, 2000; Bhagwat and Lane, 2004), Prunus serotina Ehrh. (Hammatt and Grant, 1998) and for Prunus cerasus L. (Tang et al., 2000) were inconsistent with the mentioned data obtained for other taxa of the genus Prunus, according to which the WP medium is distinguished as the best medium for the induction. Most of these studies were concerned with genotype as the one of major factor affecting induction efficiency. There are a relatively small number of papers on the maintenance of the callus of the genus Prunus on nutrient media in a friable state (Fajerska, 2006). Data mostly refer to the species which are important for research in agriculture, while the same data regarding the species of ornamental cherries from the group Sato-zakura do not exist. 
398

Parameter which was also used to determine the performance of callus induction was the speed of induction, measured in days, after placing the explants into in vitro conditions. The obtained results ( 6 to 17.2 days) fit into the expected values for the process of callognesis (Mihaljević et al., 2002; Pérez-Jiménez et al., 2012, 2013; Gerszberg et al., 2016). According to Bhagwat and Lane (2004) the callus induction for two varieties of cherries is established within a 7 days. In addition, Pérez-Jiménez et al. (2013) recorded a mean time of callus induction expressed in days - from 14.4 to 17.3 for the $P$.persica (L.) Batsch.

\section{Conclusions}

For three ornamental Japanese cherries and two genotypes of Prunus rootstocks this study showed that the growth of calli is greatly influenced by the genotype, type of explants, combination of PGRs culture media and light conditions. The media composed of MS supplemented with NAA and BAP induced a higher percentage of callus than the other media tested. Moreover, white friable callus was obtained under dark conditions. Development of these biotechnological tools and use of vegetative parts of shoots taken from mature tissue grown in open, unprotected areas, proved to be a possible method for further research. These techniques are valuable for the assessment and pretreatment of ornamental Prunus propagation protocol and should be used in further research of callus fusion and evaluation process of (in)-compatibility.

\section{Acknowledgements}

This work was supported by the Ministry of Education and Science of the Republic of Serbia within the project no. 43007 for the period 2011-2017.

\section{References}

Ainsley PJ, Collins GG, Sedgley M (2000). Adventitious shoot regeneration from leaf explants of almond (Prunus dulcis Mill). In Vitro Cellular \& Developmental Biology - Plant 36(6):470-474.

Akita M, Negishi K, Kitano A, Iwasaki M, Komae R, Ohta Y, Kuriu T, Takii T (2006). Mass propagation of cherry (Cerasus yedoensis Matsum.) through shoot primordia, Acta Horticulturae 725:579-584.

Bhagwat B, David Lane W (2004). In vitro shoot regeneration from leaves of sweet cherry (Prunus avium) 'Lapins' and 'Sweetheart'. Plant Cell, Tissueand Organ Culture 78(2):173-181.

CaponettiJD, Hall GC, FarmerJrRE(1971). In vitro growth of black cherry callus: effects of medium, environment and clone. Botanical Gazette 132(4):313-318.

Cheong EJ, Pooler M (2004). Factors affecting somatic embryogenesis in Prunusincisa 'February Pink'. Plant Cell Reports 22(11):810-815.

Declerck V, Korban SS (1996). Influence of growth regulators and carbon sources on callus induction, growth and morphogenesis from leaf tissues of peach (Prunuspersica L. Batsch). The Journal of Horticultural Science and Biotechnology 71(1):49-55.

Dorić D, Ognjanov V, Ljubojević M, Barać G, Dulić J, Pranjić A, Dugalić K
(2014). Rapid propagation of sweet and sour cherry rootstocks. Notulae Botanicae Horti Agrobotanici 42:488-494.

Druart P (1980). Plantlet regeneration from root callus of different Prunus species. Scientia Horticulturae 12(4):339-342.

Druart P (1999). Somatic embryogenesis in Prunus species. In: Jain M, Gupta P, Newton R (Eds.) Somatic embryogenesis in woody plants. Kluwer Academic Publishers, Dordrecht, pp 215-235.

Druart P (2013). Micropropagation of Prunus species relevant to cherry fruit production. Methods in Molecular Biology 11013:119-136.

Duta M, Oprea MI, Concioiu ME (2007). Prunus serrulata var. Kanzan behaviour regarding in vitro rooting and acclimatization. Scientific Papers of the RI.F.G. PitestiXXV:202-206.

Duckett CM, Oparka KJ, Prior DAM, Dolan L, Roberts K (1994). Dye coupling in the root epidermis of Arabidopsis is progressively reduced duringdevelopment. Development 120:3247-3255.

Errea P, Felipe A, Herrero M (1994). Graft establishment between compatible and incompatible Prunus spp. Journal of Experimental Botany 45(272):393-401.

Errea P, Garay L, Marin JA (2001). Early detection of graft incompatibility in apricot (Prunus armeniaca) using in vitro techniques. Physiologia Plantarum 112(1):135-141.

Fajerska EH (2006). Improvement of growth parameters of prune callus cultures destined to initiate cell suspensions. Acta Societatis Botanicorum Poloniae 75(1):5-9.

Feeney M, Bhagwat B, Mitchell JS, David Lane W (2007). Shoot regeneration from organogenic callus of sweet cherry (Prunus avium L.). Plant Cell, Tissue and Organ Culture 90(2):201-214.

Garin E, Grenier E, Grenier-De March G (1997). Somatic embryogenesis in wild cherry (Prunus avium). Plant Cell, Tissue and Organ Culture 48:83-91.

Gaspar T, Kevers C, Greppin H, Thorpe DM (1996). Plant growth regulators in plant tissue culture. In Vitro Cellular \& Developmental Biology-Plant 32:272-289.

Gentile A, Monticelli S, Damiano C (2002). Adventitious shoot regeneration in peach (Prunus persica (L.) Batsch). Plant Cell Reports 20(11):1011-1016.

Gerszberg A,Hnatuszko-Konka K, Kowalczyk T, KononowiczAK(2016). Efficient in vitro callus induction and plant regeneration protocol for different Polish tomato cultivars. Notulae Botanicae Horti Agrobotanici 44(2):452-458.

Grbić M (2004). Vegetativno razmnožavanje ukrasnog drveća i žbunja, [Vegetative propagation of ornamental trees and shrubs]. Ne \& Bo Tragovi, Beograd pp 488.

Hammatt N, Grant NJ (1998). Shoot regeneration from leaves of Prunus serotina Ehrh. (black cherry) and P. avium L. (wild cherry). Plant Cell Reports 17(6-7):526-530.

Hokanson KE, Pooler, MR (2000). Regeneration of ornamental cherry (Prunus) taxa from mature stored seed. HortScience 35(4):745-748.

Ikeuchi M, Sugimoto K, Iwase A (2013). Plant Callus: Mechanisms of induction and repression. The Plant Cell 25:3159-3173.

Ishikura N (1994). Prunus $\times$ yedoensis: in vitro culture and the production of flavonoids. Medicinal and Aromatic Plants VI, Biotechnology in 
Agriculture and Forestry 6:283-298.

Işikalan Ç, Akbaş F, Namli S, Başaran D (2010). Adventitious shoot development from leaf and stem explants of Amygdalus communis L. $c v$. Yaltinski.Plant Omics Journal 3(3):92-96.

Jayaraman S, Daud NH, Halis R, Mohamed R (2014). Effects of plant growth regulators, carbon sources and $\mathrm{pH}$ values on callus induction in Aquilaria malaccensis leaf explants and characteristics of the resultant calli. Journal of Forestry Research 25(3):535-540.

Jones OP, Hopgood ME (1979). The successful propagation in vitro of two rootstock of Prunus: the plum rootstock Pixy (P. insititia) and the cherry rootstock F12/1 ( $P$. avium). The Journal of Horticultural Science, 54(1):63-66.

Jones OP, Gayner A, Watkins R (1984). Plant regeneration from callus tissue cultures of the cherry rootstock Colt (Prunus avium $\times P$. pseudocerasus) and the apple rootstock M. 25 (Maluspumila).Journal of Horticultural Science 59:463-467.

Kalinina A, Brown CWD (2007). Micropropagation of ornamental Prunus spp. and GF305 peach, a Prunus viral indicator, Cell Biology and Morphogenesis. Plant Cell Reports 26(7):927-935.

Kato S, Matsumoto A, Yoshimura K, Katsuki T, Iwamoto K, Tsuda Y, ... Yoshimaru $\mathrm{H}$ (2012). Clone identification in Japanese flowering cherry (Prunus subgenus Cerasus) cultivars using nuclear SSR markers. BreedingScience 62(3):248-255

Lloyd G, McCown B (1980). Commercially-feasible micropropagation of mountain laurel, Kalmia latifolia, by use of shoot-tip culture. Combined Proceedings International Plant Propagators Society 30:421-427.

Mahdavian M, Bouzarl N, Abdollahi H (2011). Effect of media and plant growth regulators on micropropagation of a dwarfing cherry rootstocks (PHL-A). Biharean Biologist 5(2)86-90.

Matsuta N, Hirabayashi T, Akihama T (1983). Plantlet formation from leaf callus of Prunus lannesiana Wils. Japanese Journal of Breeding 33(4):484-486.

Matt A, Jehle JA (2005). In vitro plant regeneration from leaves and internode sections of sweet cherry cultivars (Prunus avium L.). Plant Cell Reports 24(8):468-476.

Mihaljević S, Bjedov I, Kovač M, Leljak Levanić DL, Jelaska S (2002). Effect of explant source and growth regulators on in vitro callus growth of Taxus baccata L. Washingtonii. Food Technology and Biotechnology 40(4):299-303.

Miletić R, Žikić M, Mitić N, Nikolić R (2008). Identification and in vitro propagation of 6 promising 'Oblačinska' sour cherry selections in eastern Serbia. Acta Horticulturae 795:159-162.

Mng'omba SA, du Toit ES, Akinnifesi FK (2008). Early recognition of graft compatibility in Upaca kirkiana Muell Arg. clones, provenances and species. Agroforestry Systems 74(2):173-183.

Murashige T, Skoog F (1962). A revised medium for rapid growth and bioassays with tobacco tissue culture. Physiologia Plantarum 15(3):473497.

Ning GG, Fan XI, Huang WJ, Bao MZ, Zhang JB. (2007). Micropropagation of six Prunus mume cultivars through axillary shoot proliferation, and ISSR analysis of cloned plants. Acta Biologica Cracoviensia. Series Botanica 49(1):25-31.
Neil JG, Neil H (2000). Adventitious shoot development from wild cherry (Prunus avium L.) leaves. New Forestry 20:287-295.

Nešković M, Ćulafić Lj, Konjević R (2010). Fiziologija biljaka [Plant Physiology]. Drugo dopunjeno izdanje, NNN International. ISBN 978-86-83635-92-4(335).

Nito N, Han SH, Katayama Y (2005). Evaluation of graft compatibility for taxonomically relationships among species of the orange subfamily. Acta Horticulturae 692:85-90.

Pascual L, Marin JA (2005). A liquid 2.4D pulse increased shoot and root regeneration from leaf explants of adult Prunus rootstocks. Scientia Horticulturae 106(4):582-592.

Pérez-Jiménez M, López-Soto MB, Cos-Terrer J (2013). In vitro callus induction from adult tissues of peach (Prunus persica L. Batsch). In Vitro Cellular \& Developmental Biology-Plant 49(1):79-84.

Pérez-Jiménez M, Carrillo-Navarro A, Cos-Terrer J (2012). Regeneration of peach (Prunus persica L. Batsch) cultivars and Prunus persica $\times$ Prunus dulcis rootstocks via organogenesis. Plant Cell, Tissue and Organ Culture 108(1):55-62.

Pina A,Errea P, Schulz A, Martens HJ (2009). Cell-to-cell transport through plasmodesmata in tree callus cultures. Tree Physiology 29:809-818.

Pierik RLM (1987). In vitro culture of higher plants. Springer Netherlands, Dordrechtpp 348.

Ružić $Đ$, Cerović R, Vujović T (2010). Uspostavljanje aseptične kulture in vitro novih vegetativnih podloga za trešnju, krušku i šljivu, [Establishement of aseptic culture in vitro for new vegetative rootstocks for cherry, pear and plum]. Voćarstvo 44(169/170):35-41.

Schenk RU, Hildebrandt AC (1972). Medium and techniques for induction and growth of monocotyledonous and dicotyledonous plant cell cultures. Canadian Journal of Botany 50(1):199-204.

Siwach P, Grover K, Gill AR (2011). The influence of plant growth regulators, explant nature and sucrose concentration on in vitro callus growth of Thevetia perwiviana Schum. Asian Journal of Biotechnology 3:280-292.

TangH, RenZ, Krczal G (2000). Somatic embryogenesis and organogenesis from immature embryo cotyledons of three sour cherry cultivars (PrunuscerasusL.). Scientia Horticulturae 83(2):109-126.

TodićS, BešlićZ, Kuljančić I (2005). Varying degree of grafting compatibility between cv. Chardonnay, Merlot and different grapevine rootstocks. Journal Central European Agriculture 6(2):115-120.

Trinchera A, Pandozy G, Rinaldi S, Crinò P, Temperini O, Rea E (2013). Graft union formation in artichoke grafting on to wild and cultivated cardoon: An anatomical study. Journal of Plant Physiology 170 (18):1569-1578.

Vujović T, Ružić Đ, Cerović R, Surlan Momirović G (2010). Adventitious regeneration in blackberry (Rubus fruticosus $\mathrm{L}$.) and assessment of genetic stability in regenerants. Plant Growth Regulation 61:265-275.

Yao JL, Atkinson D, Richardson R, Morris K (1995). Regeneration of transgenic plants from the commercial apple cultivar Royal Gala. Plant Cell Reports 14:407-412.

Zhou H, MingL, Zhao X, Fan X, GuoA (2010). Plant regeneration from in vitro leaves of the peach rootstock 'Nemaguard' (Prunus persica $\times P$. davidiana). Plant Cell Tissue and Organ Culture 101(1):79-87. 